\title{
Strategic Entrepreneurship and Performance of Small and Medium Scale Enterprises in Aba Metropolis
}

\author{
Olubisi Grace Makinde \\ Department of Business Administration and Marketing \\ Babcock University, Nigeria \\ Carolyn Ugochi Agu \\ Department of Business Administration and Marketing \\ Babcock University, Nigeria
}

\begin{abstract}
Strategic entrepreneurship has become dominant in the contemporary world and it is considered an effective tool for economic. Small and medium scale enterprises (SMEs) in Aba metropolis are faced with issues like inadequate information about strategic entrepreneurship, low entrepreneurial innovation which had resulted into low productivity and inefficiency in profit maximization. Little attention have been given into how strategic entrepreneurship contributes to performance of SMEs in Aba metropolis, Abia State. This study examined the effect of strategic entrepreneurship on performance of selected SMEs in Aba metropolis. The study adopted the survey research design. The population of the study consisted of 231 owner/managers of the selected SMEs in the manufacturing, the finance, health and the food and beverages sectors in Aba metropolis. The total enumeration method of sampling was used and data were gathered through the use of a questionnaire. The instrument was validated and the KMO values were greater that 0.5 while the reliability test was 0.875 . Data were analyzed using simple linear regression analysis. The results revealed that strategic entrepreneurship variables have effects on the performance variables. The study concluded that strategic entrepreneurship plays an important role in enhancing the performance of SMEs in Aba metropolis. It was therefore recommended that SMEs should pay critical attention to the adoption of strategic entrepreneurship due to its positive effect on performance.
\end{abstract}

Keywords: Entrepreneurial education, Entrepreneurial knowledge, Entrepreneurial leadership, Entrepreneurial orientation, SME Performance, Strategic entrepreneurship

\section{INTRODUCTION}

Strategic entrepreneurship has been touted as one of the fundamental instrument for superior performance by simultaneously seeking opportunities and advantages through organizational activities. (Dapend, Jin \& Songting, 2016; Ireland, Hitt \& Sirmon, 2003). The challenge of globalization has led to intense competition in the business world thereby gearing organisations into finding ways by which they can achieve and sustain their performance in the global market. (Agarwal \& Ashwani, 2008). Rigidity, risk aversion, and exhaustion heightened by mechanistic organizations obstruct the development of entrepreneurial activities. Consequently, entrepreneurial organizations which are change-oriented and which favour risk taking and continuous innovation are gaining greater popularity (Kantur, 2016).

Strategic entrepreneurship is potentially a business function which has become a key element of the strategy of every SME in their efforts to establish and maintain their competitive edge in the market (Foss \& Lyngsie, 2011). By employing strategic entrepreneurship methods, SMEs can gain meaningful direction and the ability to illustrate its success to key stakeholders (Kuratko \& Audretsch, 2017). A strategic plan also needs to be inculcated because without a 
strategic plan, SMEs may lose its direction, unknowingly drift away from its values, and lack the ability in adequate delivery of its services or products to its clients (Majama \& Magang, 2017). Thus, strategic entrepreneurship is established with how firms' strategic intent can facilitate continuous leveraging of entrepreneurial opportunities for advantage seeking purposes in order to create wealth (Foss \& Lyngsie, 2011).

According to Audretsch, Lehmann, Belitski and Cajazza (2018), large companies are more successful than SMEs because the large companies plan strategically, thus, the need for SMEs to also plan strategically to have competitive advantage. With strategic entrepreneurship, firms are able to highlight their development and growth options, look deeply into their opportunities and strategically plan to fully exploit the opportunities presented. Strategic entrepreneurship exceeds hierarchical levels, applies to both small and large firms, established firms as well as new ventures (Agarwal, Audretsch \& Sarkar, 2010). Thus, strategic entrepreneurship is linked with how firms' strategic intent can facilitate continuous leveraging of entrepreneurial opportunities for advantage seeking purposes in order to create wealth (Foss \& Lyngsie, 2011). Zafar \& Mustafa (2017) opines that commitment from every stakeholders will enable strategic entrepreneurship will ensure the success in the revamping the SMEs as engines of growth in the economy and a viable tool for the development of indigenous technology, rapid industrialization, generation of employment and the pivot for sustainable economic development.

The Federal and State Government places great emphasis on the development of small and medium scale enterprises (SMEs) with the view to improving the economy through the provision of special support and protection of SMEs (Eniola, 2014). This is because the SMEs ensures capacity building through production of goods, improves exports and earn foreign exchange for the country thereby improving the foreign reserve (Oni \& Daniya, 2012).

Given the importance of small and medium scale enterprises to economic and social development, their lack of longevity, is however a cause for concern because the survival of business is critical to the sustainability of economies (Mohammed \& Obeleagu-Nzelibe, 2014). It has been estimated that, internationally, only $30 \%$ of SMEs survive to the second generation, while fewer than $14 \%$ make it beyond the third generation (Majama \& Magang, 2017).

According to Mohammed and Obeleagu-Nzelibe (2014), the increase in the failure rate of SMEs in Aba metropolis is of great concern. One of the major challenges of the growth of SMEs in Aba metropolis is that most of them do not engage in strategic entrepreneurship because they find it difficult to combine opportunity and advantage seeking behaviours together at the same time (Schindehutte \& Morris, 2009). SME owners/managers in Abia State have been accused of being strategically myopic and lacking the long-term vision as regards where their company is headed. The concern is that by neglecting strategic entrepreneurship, SMEs may not achieve their full performance and growth potentials, and their survival could be at risk. Most SMEs operating in Aba metropolis lack entrepreneurial education and this has led to lack of entrepreneurial efficiency in the areas of low capital outlays, the use of labour intensive technology, low level of skills and organization, limited access to organized markets and formal credit, unregulated and competitive markets, limited access to services, lack of adequate reinvestment, and unrealized earnings and profit (Burger, O'Neil \& Mahadea, 2005; Dauda, 2007). Also, the importance of entrepreneurial leadership has not been fully studied in Aba metropolis and this has led to a high employee turnover intention of the SMEs due to lack of strategy by the leaders (Saasongu, 2015). About 80 percent of businesses in Aba metropolis 
lack entrepreneurship skills and this is greatly affecting their growth not only on the local market but also in the region. This shows that they are not taking advantage of their potential.

Furthermore, the study of entrepreneurial knowledge has not been fully inculcated in SME employees in Aba metropolis as this can be done through oral during formal or informal meetings (Mohammed \& Obeleagu-Nzelibe, 2014). This has led to lack of entrepreneurial skills of the employees in the areas of resiliency, ability to focus, investing for the long-term, selfreflection and self-reliance (Mohammed \& Obeleagu-Nzelibe, 2014). It has also been indicated that SME employees in Aba metropolis lack entrepreneurial orientation which has led to low entrepreneurial innovation of market products, technology and lack of exposure to new business opportunities and also lack of competitive advantage in the business environment (Eleodinmuo, 2015). Schindehutte and Morris (2009) stated that strategic entrepreneurship is more than intersection of strategic management and entrepreneurship and should be treated as a contested idea and not as a settled issue.

SMEs in Aba metropolis have not invested adequate resources on the utilization of modern technologies, and this has led to the decline in the designing and development of new products (Eleodinmuo \& Onwumere, 2015). This situation has affected the present and future growth of the enterprise leading them to go into extinction. SMEs in Aba metropolis lack healthy competition in the sector and this has led to decline in their sales volume and inability to achieve their marketing and corporate goals. This has also led to a difficulty in their survival and as a result, the performance and efficiency of small and medium scale businesses as a tool for growth and development in Nigeria is not being realized. Various studies have been conducted on the effect on entrepreneurship development but not much has been done on strategic entrepreneurship and SME performance as it relates to Nigeria and specifically Aba metropolis (Bengesi \& Roux, 2014; Luke, 2009; Mohutsiwa, 2012; Akhamiokhor \& Adanikin, 2017; Obiwuru, Okwu, Akpa \& Nwankwere, 2011). Therefore, there was a need to investigate the effect of strategic entrepreneurship on the performance of small and medium scale enterprises in the Aba metropolis, Abia State.

\section{LITERATURE REVIEW}

\section{Strategic Entrepreneurship}

Strategic Entrepreneurship refers to the connection between entrepreneurship and strategic management literature (Kuratko \& Audretsch, 2017). It can also be described as the integration of entrepreneurial (opportunity-seeking actions) with strategic (advantage-seeking actions) perspectives to design and implement entrepreneurial strategies that create wealth (Hitt, Duane, Camp \& Sexton, 2001). Strategic entrepreneurship has emerged through a combination of strategic management literature and entrepreneurship literature (Simmons, 2010). It incorporates aspects from both fields to combine entrepreneurial actions with strategic perspective (Ireland, Hitt \& Sirmon, 2003; Simmons, 2010).

According to Duane, Ireland, Hitt \& Sirmon (2003), strategic entrepreneurship is the action of simultaneously engaging in the search for opportunities and competitive advantage for devising and implementing entrepreneurial strategies that create wealth. Further constructs of strategic entrepreneurship are the application of creativity and the development of innovation. First movers in innovation impact significantly on competitors' market power and enjoy, potentially transient, monopoly advantages and abnormal profits because of the slower actions of competitors (Qosja, 2014). According to Hitt et al. (2001), innovations resulting from new combinations of production factors are critical to a firm's wealth-creating efforts. Innovation is linked to successful performance of organisations in both the industrial and service sectors as well as to the greater economy as a whole (Salisu \& Abu Bakar, 2018). Effective innovations 
create new value for customers, thereby, enhancing the performance of the organization which makes creativity an essential element for increased performance (Padachi, 2012 \& Mohutsiwa, 2012). Eleodinmuo and Onwumere (2015) argued that creativity is increasingly important for small and medium scale enterprises as it opens doors for multiple opportunities. Creativity as a continuous process rather than the outcome of a single act is the basis of innovation and is encouraged when the resources supporting it are managed strategically.

Hitt, Ireland, Camp and Sexton (2001), sought to define, legitimize and clarify the domain of strategic entrepreneurship. They argued that in order for firms to achieve sustained competitive advantage, they need to strategically leverage entrepreneurial wealth creation.

\section{Entrepreneurial Education}

Entrepreneurial education emphasizes on teaching the workers or employees with the passion and desired skills needed to create an entrepreneurial firm and guide the firm successfully through its initial stage to maturity stage. It seeks to provide SMEs "with the knowledge, skills and motivation to encourage entrepreneurial success in a variety of settings" (Izedonmi \& Okafor, 2010; Maria, 2010). This would enhance necessary identification and avoidance of many pitfalls awaiting the less well trained and vigilant entrepreneurs. The training in entrepreneurial education may initially be perceived as a cost in terms of time and money but it would eventually be appreciated (Yusuf, 2017). Entrepreneurship education is designed to communicate and inculcate competencies, skills, knowledge, and values needed to recognize business opportunity, organize and start new business venture (Njenga \& Theuri, 2016). The expected goal of entrepreneurial education is to inculcate the SMEs trainees with the ability to; identify and solve problems using critical and creative thinking, effectively work with others as proactive team members to cultivate the ability to resolve conflict. Also, the goal of entrepreneurial education to SMEs trainees or employees involves the ability to collect, analyze, organize and critically evaluate information, communicate and negotiate effectively (Qosja, 2014).

\section{Entrepreneurial Leadership}

Entrepreneurial leadership is conceived as the ability to influence others to manage resources strategically in order to identify and display opportunity and advantage seeking behaviour (Covin \& Slevin, 2002). Entrepreneurial leadership has also been defined as the process of creating an entrepreneurial vision and inspiring a team to enact the vision in high velocity and in uncertain environments (Kuratko \& Audretsch, 2017, Chen, 2007; Gupta, MacMillan \& Surie, 2004; Surie \& Ashley, 2008). This definition has three main components such as: proactiveness: being active to influence and lead the future rather than waiting to be influenced by it; exploiting opportunities and accepting the responsibility of failure (Kuratko, 2017); being able to anticipate future problems, needs for change, and improvement (Okudan \& Rzasa, 2006); and responding to environmental opportunities (Surie \& Ashley, 2008). Innovativeness, the ability and tendency to think creatively, develop novel and useful ideas in opportunity recognition, resources utilization and problem solving (Claudino, Santos, Cabral, \& Pessoa, 2017); the distinctive attribute that differentiates entrepreneurs from those that want to be self-employed. Risk taking, the willingness to absorb uncertainty and take the burden of responsibility for the future (Chen, 2007). Risk taking is one of the characteristics of an entrepreneurial leader during the early stages of the venture but the risk taken should in a prudential manner (Agbim, Oriarewo \& Owutuamor, 2013). To be effective, entrepreneurs should seek opportunity to internalize and practice all the skills that are associated with the entrepreneurial leadership components (Okudan \& Rzasa, 2006). Also, Avolio and Yammarino 
(2013) pointed out that the activities of the SMEs' leaders relate to leadership which is the allimportant driving force of any organization.

Entrepreneurial leadership capability helps entrepreneurs to cope with the challenges associated with new venture creation, growth and success, and to deal with competitive business environment (Cogliser \& Brigham, 2004). Entrepreneurs, thus, need to develop entrepreneurial leadership capabilities so as to gain competitive advantage and achieve sustained entrepreneurial success in their ventures (Madanchian \& Taherdoost, 2017).

\section{Entrepreneurial Knowledge}

Entrepreneurial knowledge explains "the ability to recognize or create an opportunity and take action aimed at realizing an innovative knowledge practice or product" (Didenko \& Pliego, 2014). Entrepreneurial knowledge is the way an individual appreciates skills concepts and mentality which is expected of an entrepreneur (Tshikovhi \& Shamdare, 2015). Entrepreneurship knowledge focuses on opportunities which is aimed at improving the "production" and "personal transformation" rather than the economic entrepreneurship which is aimed at monetary profit. Matzler, (2008) argued that entrepreneurial knowledge is the most suitable form of entrepreneurship. Massad and Tucker (2009) articulated that entrepreneurial knowledge can be acquired and developed through consistent exposure to entrepreneurship activities. Small and medium scale enterprises need entrepreneurial knowledge to be creative. Small and medium scale enterprises need entrepreneurial knowledge on the skills such as interpersonal skills and critical and creative skills needed to grow the businesses (Audretsch, Lehmann, Belitski \& Caiazza, 2018). It was further posited that entrepreneurial knowledge is need by SMEs in order to know how to raise capital, discover a model that is sustainable, to improve the services rendered and to understand the needs of the customers.

\section{Entrepreneurial Orientation}

Entrepreneurial orientation has been defined as all the decision-making activities that lead to a new market entry and the support of business activities (Kropp, Lindsay \& Shoham, 2006). Entrepreneurial orientation also refers to the strategy making practices that businesses implement to identify and launch new ventures (Farja, Gimmon \& Greenberg, 2016). Entrepreneurial orientation has its roots in strategy-making process literature .The construct, as it is commonly defined today, is first described as an entrepreneurial organization, a multidimensional concept, that engages in product market innovation, undertakes somewhat risky ventures and is first to come up with 'proactive' innovations, beating competitors to the punch (Covin \&Wales, 2012). Application of entrepreneurial orientation would enable small business enterprises to have access to capital and hence, its performance could be improved (Sidek, Mohamad \& Nasir, 2016). Rezaei \& Ortt (2018) pointed out that top managers with high rate of entrepreneurial orientation who are willing to take risk, show high degree of competitive advantage and imbibe innovative activities have positive relationship to performance of the firm. According to Sidek, Mohamad \& Nasir (2016), the firms that have entrepreneurial orientation are more focused towards achieving their objectives and make more effort toward seeking opportunities from supply of capital. Firms that create effective strategic orientation can make more return on investment and profits and attract more external finances (Cheng, Ioannou, \& Serafeim, 2014).

\section{Performance}

According to Bassey \& Tapeng (2012), performance is the result of an effort resulting from actions which an organization has undertaken which covers various activities such as human resources, finance, production and marketing. Business performance also consists of all effort 
by an organization to attain its set goals consisting but not limited to survival, employee, customer and satisfaction, sales growth and profitability (Mark \& Nwaiwu, 2015). It was further opined that business performance entails the views about the values provided and received by customers.

The predictable approach to firm's performance has been to consider the financial approach. Another approach to organisational performance is to use measurement against purpose and perceptual measures of company performance. Park and Luo (2001) asserted that similar approach to assessing the level of satisfaction can arise from specific factors and actions. Subsequently, performance measurement has come from the areas of organisational theory and strategic management; hence, organisational performance can be measured using financial measures, non-financial measures or a combination of both.

\section{Entrepreneurial Efficiency}

Efficiency is defined as "the capacity of an organization, institution, or business to produce desired results with a minimum expenditure of energy, time, money, personnel, material" (Mesh, 2012 in Nyaga, 2015). Cummins (2003) as used by Abanis, Byamukama, Burani, Ibrahim and Novembrieta (2013) defined entrepreneurial efficiency in terms of 'profitability and growth'. Profitability ratios are critical ways of identifying and measuring the financial situation of a business organization. When the profitability of an organization is declining compared to other firms in the same industry, then the firm is considered to be financially weak (Abanis, Arthur, Byamukama, Burani, Ibrahim, \& Novembrieta, 2013). Efficient firms grow and survive even in the midst of economic downturns. Firms operating below the minimum efficient scale which are unable to overcome the diseconomies of scale are forced out of the industry. Efficient firms grow faster than their counterparts as they tend to overcome their initial scale disadvantage by investing gradually in the enterprise or firm (Abanis et al, 2013).

\section{Employee Turnover Intention}

Maylew (2013), defines employee turnover "as the number of employees who leave an organization and are replaced by new ones" Ross (2014 sees the concept as a method of replacing an employee with a new employee which can be measured at a percentage rate. Turnover can be classified as an important part of performance indicator which will affect every other aspect of an organization and it can occur due to various reasons which may be expected or not expected (Nowak, Holmes \& Murrow, 2010; Kurnat-Thoma, Ganger, Peterson \& Channell, 2017). Employee turnover is referred to as the "rate at which an employer gains and losses employee" which can harm the organisation's efficiency in that highly skilled workers often leave the organization (Armstrong, 2006) and for service oriented firms, it can lead to dissatisfaction on the part of customers because a customer feels uncomfortable seeing new persons at every contact (Brian, 2009). The organization is usually at the receiving end because the cost of losing an experienced employee is greater than paying a higher wage (Kumar, Ramendran \& Yacob, 2012).

The employee turnover intention has been described as the decision making process of voluntary turnover (Kim, Kim \& Rhee, 2017). The willingness to leave is known as employee turnover intention (Hongvichit, 2015). Employee turnover will lead organization to face operational disruption due to the difficulty in replacing the skilled and ability employees and also, the demoralization of organizational membership will be increased. In order to reduce employee turnover rate, the leadership of the enterprise should play a crucial role in increasing the enterprises and employees' performance through incentives and motivation which will 
yield high productivity and the attainment of the enterprise's vision. (Gul, Ahmad, Rehman, Shabir, \& Razzaq, 2012).

\section{Entrepreneurial Skills}

Entrepreneurial skills can be defined as knowledge demonstrated by actions or the ability to perform in a certain way and are acquired through training and education (Bosire \& Nzaramba, 2013). It can also be defined as the capabilities an entrepreneur possesses in order to run a business (Hisrich \& Peter, 2002). Entrepreneurial skills enable an entrepreneur to identify customer needs, technical and market opportunities, generate ideas, develop products /services to meet the needs, and acquire information about the potential opportunity domain and knowledge (Omare \& Kyongo, 2017). Specific entrepreneurial and business skills are essential for the success of SMEs. According to Afolabi and Macheke (2012), the absence or low levels of key skills like motivation, ability to gather resources, financial management, human resource management, marketing and technical skills, may lead to zero performance, while weakness in a particular element would decrease effectiveness in the overall performance of the venture. This thus, means that the increase in the capacity of any of these skills can lead to an increase in the entrepreneurial performance of the entrepreneur (Afolabi \& Macheke, 2012).

\section{Entrepreneurial Innovation}

Entrepreneurial innovation can be defined as "the willingness to support creativity and experimentation in the introduction of new products or services" which involves research \& development in the development of processes (Lumpkin \& Dess, 2001). Innovation is paramount to the survival and growth of any business (Martin \& Namusonge, 2014). It has changed the way companies conduct their businesses and the ways of satisfying the needs of customers. Small and Medium Enterprises (SMEs) constitute 99.7\% of the enterprises worldwide (Agarwal \& Ashwani, 2008). Since Small and Medium Enterprises (SMEs) contribute substantially to the economic and industrial development in most countries, it becomes crucial to study innovation in SMEs ( Ebitu, Basil \& Ufot, 2016).

According to Lumpkin and Dess (2001), product-market innovativeness places emphasis on the design of the product, the market research, advertisement and promotion while technological innovation deals with the process and technological development. The innovative propensity of an organization influences the extent to which profit outcomes persist over time, thus, more innovation is equal to greater profit (Eleodinmuo \& Onwumere, 2015). Innovation is dependent on a variety of factors, such as innovative behaviour, work environment, learning orientation and organizational learning procedure (Zahra, Ireland \& Hitt, 2000; Kleysen \&Street, 2001). Despite the roles of innovation in ensuring productivity gains, SMEs faces various challenges especially in developing economies like Nigeria which include limited human and financial capabilities, poor infrastructural development, unfavourable policies on the part of government which inhibits innovative activities (Abdu \& Jibir, 2017)

\section{Resource Based View of the Firm}

\section{THEORETICAL REVIEW}

Resource Based View (RBV) was propounded by Wernerfelt in 1984. Wernerfelt (1984) in his analysis of RBV explained the strategic options of a firm for choosing resources. The theory explains the origin or competitive advantage of a firm and supports that the intangible resources are the main concern that ensures performance of a firm (Barney, Ketchen \& Wright, 2011; Galbreath \& Galvin, 2006; Liu, Timothy \& Gao, 2010). Studies have revealed the 
relationships between organisational resources, capabilities, performance through RBV (Barney 2007; Meutia \& Ismail, 2012; Ogunyomi \& Bruning, 2015; Ibrahim \& Shariff, 2016).

The RBV has been critisised for the reason that there are no managerial implications and it is also viewed as limited in its application in that the sustained competitive advantage is not achievable Kraaijenbrink, Spender \& Groen (2010). Tywoniak (2007) stated that the usefulness of RBV appears to be greater in terms of generating understanding and providing a structure for strategizing. Barney (2001) also stated that resource based logic can help managers to completely understand the kind of resources that help generate sustained strategic advantages, help them use this understanding to evaluate the full range of resources their firm may possess, and then exploit those resources that have the potential to generate sustained strategic advantage.

Resource based view acknowledged that the human resources in form of skills, competencies and capabilities are the key components of entrepreneurship education. The theory is relevant to the study as it involves acquisition of entrepreneurial skills through entrepreneurial education and entrepreneurial knowledge, adoption and use of technology by the small and medium scale enterprises in order to enhance their overall performance. Thus, in this study, the postulates of RBV were used to inform the independent variables.

\section{Research Model and Hypotheses Development}

This study explores the effect of strategic entrepreneurship on the performance of small and medium scale enterprises. Strategic entrepreneurship comprise Entrepreneurial education, Entrepreneurial leadership, Entrepreneurial knowledge, and Entrepreneurial orientation. On the other hand, performance entails entrepreneurial efficiency, employee turnover intention, entrepreneurial skills, and entrepreneurial innovation.

\section{Entrepreneurial Education on Entrepreneurial Efficiency}

Yusuf (2017) established that entrepreneurial education has effect efficiency of SMEs in Nigeria since entrepreneurial education leads to improved skills and competencies which positively boosted performance of SMEs, which in turn has a multiplier effect on the economic recovery and growth of Nigeria. This confirmed the study of Mitchelmore and Rowley (2010) that acquiring entrepreneurial competencies positively impacted on the business performance of SMEs. Furthermore, Mohammed and Nzelibe (2014) also established that entrepreneurship education had significant effect on the business success of SMEs in Nigeria. Similarly, Bosire and Nzaramba (2015) reported that entrepreneurship education do lead to better business practices and increased revenues and profits in SMEs. They concluded that lack of entrepreneurship education is an important factor that limit the growth of SMEs.

The study of Yusuf (2017) also revealed that acquisition of entrepreneurship education, implementation of technological devices and platforms, as well as, globalisation enhances efficiency and profitability of SMEs in Nigeria. The study of Barchue and Aikaeli (2013) revealed that entrepreneurial education and access to credit do positively influence the efficiency of SMEs in Monrovia. Other studies have also and have effect on efficiency (Qosja; 2014, Njenga \& Theuri, 2016). The study of Njoroge and Gathungu (2013) revealed that the entrepreneurs were able to market their products within the district but not around the country due to inadequacy of entrepreneurial education.

$\mathbf{H}_{01}$ : Entrepreneurial education does not have significant influence on entrepreneurial efficiency of selected SMEs in Aba metropolis. 


\section{Entrepreneurial Leadership on Employee Turnover Intention}

Several researchers have done empirical reviews on the influence of entrepreneurial leadership on employee turnover. Siew (2017) revealed in his findings that there is a relationship between transformational and transactional leadership style and turnover intention within SMEs in Malaysia. This study also demonstrated that the transformational leadership style has contributed the most to turnover intention within SMEs in Malaysia by reducing the employees' turnover intention when compared with transactional leadership style. According to El Badawy and Bassiouny (2014), they stated that there is a positive impact of the transformational leadership and its ultimate impact on employee's intention to quit an organization. Their result indicates highly statistically significant positive correlation between transformational leadership and employee intention to quit. Griffith (2003), Wells and Peachey (2010), Cheng, Bartram, Karimi, and Leggat (2016) proved that the transformational leadership style helps to reduce employee turnover intention and it has been provided by the results of several studies and in various employment areas. In Griffith (2003), he stated that earlier research has associated employee job satisfaction, commitment, motivation and effort to transformational leaders.

Cheng, Bartram, Karimi and Leggat (2016) found out that in healthcare industry, transformational leadership style is capable of constructing healthier working environments and also helps in retaining nurses. Waldman, Carter and Hom (2015) conducted a study on the connection between leadership and follower turnover by investigating the effects of grouplevel transformational leadership on the withdrawal process. Through their finding, they discovered that transformational leadership predicts turnover through quit intentions and their test of cross-level moderation reveals that transformational leadership can weaken the effect of quit intentions on turnover. Therefore, their result had shown that employees are less likely to carry out quit intentions when they have transformational leaders. This outcome also supported the findings of the study of Siew (2017). It was found out that affective commitment would decline workers' quitting intention and serves to promote a degree of trust and willingness to follow their leaders' philosophy, ideology, vision and guidance in the organization (Gyensare, Anku-Tsede, Sanda, \& Okpoti 2016). Hence, affective commitment fully mediates the relationship between transformational leadership and employee turnover intention, (Gyensare, Anku-Tsede, Sanda \& Okpoti 2016). In the study of Gyensare, Kumedzro, Sanda and Boso (2017), the results showed that transformational leadership positively influenced engagement but negatively relates to employee turnover intention.

The study of Majeed, Jamshed and Mustamil (2018) revealed that there exists a negative relationship between ethical leadership and employee turnover intention and prosocial rule breaking. Furthermore, pro-social rule breaking has a positive relationship with employee turnover intention. The results of regression analysis showed that prosocial rule breaking acts as a partial mediator between ethical leadership and employee turnover intentions. Hence, the following is the second hypothesis that was developed to be tested:

$\mathbf{H}_{\mathbf{0 2}}$ : Entrepreneurial leadership has no significant effect on employee turnover intention of selected SMEs in Aba metropolis.

\section{Entrepreneurial Knowledge on Entrepreneurial Skills}

Nystrom (2012) discovered that the probability of having an adequate entrepreneurial skills depends on the level of entrepreneurial knowledge acquired. Findings indicated that entrepreneurs with higher entrepreneurial knowledge of human resources management will have high entrepreneurial skills towards human resources commitment practices and involvement practices than entrepreneurs with little or no entrepreneurial knowledge of human resources management (Tim, 2011). 
In the study of Gast, Werner and Kraus (2016), it was discovered that employees in lower management positions in small and medium scale enterprises benefit strongly from entrepreneurial knowledge spillover effects as the necessary skills, knowledge and expertise are inculcated in them because of the enabling environment and they are able to build up networks conducive to entrepreneurship activities in their enterprise. The study of Omare and Kyongo (2017) tested and confirmed the hypothesis that entrepreneurial skills have a significant effect on competitive advantage. This means that entrepreneurs who wish to succeed must embrace and inculcate entrepreneurial skills among their employees through entrepreneurial knowledge (Omare \& Kyongo, 2017).

The study of Jafarnejad, Abbaszadeh, Ebrahimi and Abtahi (2013) revealed that lack of sufficient knowledge in management skills, constitute barriers and challenges of corporate entrepreneurship development in Iranian SMEs which leads to inadequate skills and knowledge required to launch and sustain a business and also had little knowledge of the business environment. Afolabi and Macheke (2012) revealed that SMEs in the plastic industry need training in order to gain entrepreneurial knowledge in acquiring the necessary skills so as to succeed in the enterprise as most of the respondents indicated that they have not yet under gone training, while Njenga and Theuri (2016) revealed that most entrepreneurs displayed limited entrepreneurial knowledge in areas such as access to financial information, operation of a business, business planning and monitoring profitability. Consequently, the third hypothesis that was developed to be tested is:

$\mathbf{H}_{\text {03: }}$ : Entrepreneurial knowledge does not have significant effect on entrepreneurial skills of selected SMEs in Aba metropolis.

\section{Entrepreneurial Orientation on Entrepreneurial Innovation}

Bleeker (2011) revealed that when entrepreneurial orientation is considered as a onedimensional construct, it influences both the innovation process as a whole and all its individual steps. However, while entrepreneurial orientation is considered as a multidimensional construct, the only dimension that influences the innovation process and its steps is proactiveness which makes innovation a one-dimensional construct. Prior findings from the field of organizational behaviour revealed that there is a significant linkage between entrepreneurial orientation and the levels of innovations (Schueffel, 2014). Pérez-Luño, Wiklund and Cabrera (2011) also revealed in their findings that proactivity and risk taking were positively linked to the number of innovation s generated by a firm. Other scholars like Avlonitis and Salavou (2007) also presented an entire string of arguments and empirical evidence that yields support to the idea that entrepreneurial orientation has a significant positive effect on the innovation levels of a company. Based on the findings of Schueffel (2014), it was stated that the more pronounced the entrepreneurial orientation of a firm is, the higher the level of its innovation performance.

The findings of Etriya, Scholten, Wubben, Kemp and Omta (2013) revealed that entrepreneurial orientation positively affects innovation inputs, innovation adoption and innovation generation, and innovation adoption has a positive effect on performance. Madhoushi and Sadati (2011) also revealed in their study findings that entrepreneurial orientation both directly and indirectly through the knowledge management affected innovation performance while Cheng, Tang, Jin, Xie and Li (2014) found that entrepreneurial orientation is positively related to product innovation performance.

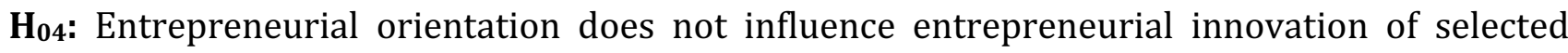
SMEs in Aba metropolis. 


\section{DATA ANALYSIS AND RESULTS}

Data analysis for this study was carried out with the use of simple linear regression analysis in SPSS to test the effect of the independent variable, strategic entrepreneurship sub-variables on the sub-variables of performance.

\section{RESULTS AND DISCUSSION}

Table 1: Regression Analysis of Entrepreneurial education on entrepreneurial efficiency of selected SMEs in Aba metropolis

\begin{tabular}{|c|c|c|c|c|c|c|}
\hline \multirow{2}{*}{\multicolumn{2}{|c|}{ Model }} & \multicolumn{2}{|c|}{$\begin{array}{c}\text { Unstandardized } \\
\text { Coefficients }\end{array}$} & \multirow{2}{*}{$\begin{array}{c}\begin{array}{c}\text { Standardized } \\
\text { Coefficients }\end{array} \\
\text { Beta } \\
\end{array}$} & \multirow[t]{2}{*}{$\mathbf{T}$} & \multirow[t]{2}{*}{ Sig. } \\
\hline & & B & Std. Error & & & \\
\hline \multirow[t]{2}{*}{1} & (Constant) & 13.016 & 1.383 & & 9.411 & .000 \\
\hline & $\begin{array}{l}\text { Entrepreneurial } \\
\text { Education }\end{array}$ & .304 & .070 & .276 & 4.340 & .001 \\
\hline & $\begin{array}{l}276 \\
076 \\
e=0.001\end{array}$ & & & & & \\
\hline
\end{tabular}

\section{a. Dependent Variable: Entrepreneurial Efficiency}

Source: Field Survey, 2018

The results of the regression analysis in table 1 revealed that eentrepreneurial education has significant influence on entrepreneurial efficiency of selected SMEs in Aba metropolis $(\beta=$ $0.304, \mathrm{t}=4.340, \mathrm{p}<0.05)$. The $\mathrm{t}$-value shows that the coefficient of the model parameter is statistically significant. The $\mathrm{R}$ square of 0.076 indicates that $7.6 \%$ of the variation in entrepreneurial efficiency of selected SMEs in Aba metropolis is explained by entrepreneurial education. The coefficient of entrepreneurial education is 0.304 which implied that a change of unit in entrepreneurial education influences a positive change of 0.304 units in the entrepreneurial efficiency of small and medium enterprises in Aba metropolis. The result is consistent with Yusuf (2017) who established similar findings that acquisition of entrepreneurship education, adoption and use of technology devices and platforms, as well as, globalisation enhances efficiency and profitability of SMEs in Nigeria. The study reported that for manufacturing SMEs to operate competitively, profitably and significantly contribute to the economic recovery and growth of Nigeria, they need to continuously acquire entrepreneurial education. Additionally, Barchue and Aikaeli (2013) also established that entrepreneurial education and access to credit do positively influence the efficiency of SMEs in Monrovia.

Table 2: Regression Analysis of Entrepreneurial Leadership on Employee Turnover Intention of selected SMEs in Aba metropolis

\begin{tabular}{|c|c|c|c|c|c|}
\hline \multirow[t]{2}{*}{ Model } & \multicolumn{2}{|c|}{ Unstandardized Coefficients } & \multirow{2}{*}{$\begin{array}{c}\begin{array}{c}\text { Standardized } \\
\text { Coefficients }\end{array} \\
\text { Beta } \\
\end{array}$} & \multirow[t]{2}{*}{$\mathbf{T}$} & \multirow[t]{2}{*}{ Sig. } \\
\hline & B & Std. Error & & & \\
\hline (Constant) & 10.678 & 1.706 & & 6.260 & .000 \\
\hline $\begin{array}{l}\text { Entrepreneurial } \\
\text { Leadership }\end{array}$ & .320 & .090 & .230 & 3.553 & .001 \\
\hline $\begin{array}{l}R=0.230 \\
R^{2}=0.053 \\
P \text {-value }=0.001\end{array}$ & & & & & \\
\hline
\end{tabular}

a. Dependent Variable: Entrepreneurial Turnover Intention Source: Field Survey, 2018 
The second hypothesis was formulated to determine whether Entrepreneurial leadership has significant effect on employee turnover intention of selected SMEs in Aba metropolis. The results of the regression analysis showed that eentrepreneurial leadership has significant effect on employee turnover intention of selected SMEs in Aba metropolis $(\beta=0.320, t=3.553$, $\mathrm{p}<0.05)$. The $\mathrm{t}$-value affirms that the coefficient of the model parameter is statistically significant $(p=0.001)$. The regression result shows $R$ square of 0.053 which indicates that $5.3 \%$ of the variation in employee turnover intention of selected SMEs in Aba metropolis is explained by entrepreneurial leadership. The regression coefficient of entrepreneurial leadership is 0.320 which implied that a unit increase in entrepreneurial leadership (that is proactive entrepreneurial behaviour) would bring about an increase of 0.320 in employee turnover intention of small and medium enterprises in Aba metropolis. The results showed a significant effect of entrepreneurial leadership on employee turnover intention of small and medium enterprises in Aba metropolis. The result is consistent with El Badawy and Bassiouny (2014) that there is a positive impact of the transformational leadership and its ultimate impact on employee's intention to quit an organization. Their result indicates highly statistically significant positive correlation between transformational leadership and employee intention to quit. This finding also supports Griffith (2003), Wells and Peachey (2010), Cheng, Bartram Karimi, and Leggat (2016) arguments that the transformational leadership style helps to reduce employee turnover intention and it has been provided by the results of several studies and in various employment areas.

Table 3: Regression Analysis of Entrepreneurial knowledge on entrepreneurial skills of selected SMEs in Aba metropolis

\begin{tabular}{|l|r|r|r|r|r|}
\hline \multirow{2}{*}{ Model } & \multicolumn{2}{|c|}{$\begin{array}{c}\text { Unstandardized } \\
\text { Coefficients }\end{array}$} & $\begin{array}{l}\text { Standardized } \\
\text { Coefficients }\end{array}$ & T & Sig. \\
\cline { 2 - 6 } & B & Std. Error & Beta & & \\
\hline (Constant) & 12.513 & 1.040 & & 12.037 & .000 \\
\hline $\begin{array}{l}\text { Entrepreneurial } \\
\text { Knowledge }\end{array}$ & .321 & .054 & .363 & 5.893 & .001 \\
\hline $\begin{array}{l}\mathrm{R}=0.363 \\
\mathrm{R}^{2}=0.132 \\
\text { P-value }=0.001\end{array}$ & & & & \\
\hline
\end{tabular}

\section{a. Dependent Variable: Entrepreneurial Skills}

Source; Field Survey, 2018

The third hypothesis was formulated to determine whether Entrepreneurial knowledge have significant effect on entrepreneurial skills of selected SMEs in Aba metropolis. The regression results show that entrepreneurial knowledge has significant effect on entrepreneurial skills of selected SMEs in Aba metropolis $(\beta=0.321, t=5.893, p<0.05)$. The $t$-value shows that the coefficient of the model parameter is statistically significant $(p=0.001)$. The R square of 0.132 indicates that $13.2 \%$ of the variation in entrepreneurial skills of selected SMEs in Aba metropolis is explained by entrepreneurial knowledge. The analysis showed that a unit increase in the entrepreneurial knowledge, that is, increasing ability to recognize or create an opportunity and take action by a unit would result in increased entrepreneurial skills by 0.321.The results showed a significant effect of entrepreneurial knowledge on entrepreneurial skills of small and medium enterprises in Aba metropolis. This finding corroborates past results of studies on the relationship between entrepreneurial knowledge and entrepreneurial skills. Nystrom (2012) found out that the probability of having an adequate entrepreneurial skill depends on the level of entrepreneurial knowledge acquired. Findings indicated that entrepreneurs with higher entrepreneurial knowledge of human resources management will have high entrepreneurial skills towards human resources commitment practices and 
involvement practices than entrepreneurs with little or no entrepreneurial knowledge of human resources management. In a similar study, Gast, Werner and Kraus (2016) found out that employees in lower management positions in small and medium scale enterprises benefit strongly from entrepreneurial knowledge spillover effects as the necessary skills, knowledge and expertise are inculcated in them because of the enabling environment and they are able to build up networks conducive to entrepreneurship activities in their enterprise.

Table 4: Regression Analysis of entrepreneurial orientation on entrepreneurial innovation of selected SMEs in Aba metropolis

\begin{tabular}{|c|c|c|c|c|c|}
\hline \multirow[t]{2}{*}{ Model } & \multicolumn{2}{|c|}{$\begin{array}{l}\text { Unstandardized } \\
\text { Coefficients }\end{array}$} & \multirow{2}{*}{$\begin{array}{c}\text { Standardized } \\
\text { Coefficients } \\
\text { Beta }\end{array}$} & \multirow[t]{2}{*}{$\mathbf{T}$} & \multirow[t]{2}{*}{ Sig. } \\
\hline & B & Std. Error & & & \\
\hline (Constant) & 14.439 & 1.014 & & 14.244 & .000 \\
\hline $\begin{array}{l}\text { Entrepreneurial } \\
\text { Orientation }\end{array}$ & .271 & .052 & .324 & 5.180 & .001 \\
\hline $\begin{array}{l}R=0.324 \\
R^{2}=0.105 \\
P \text {-value }=0.001\end{array}$ & & & & & \\
\hline
\end{tabular}

a. Dependent Variable: Entrepreneurial Innovation

Source: Field Survey, 2018

The result in table 4 showed that entrepreneurial orientation has significant influence on entrepreneurial innovation of selected SMEs in Aba metropolis $(\beta=0.271, t=5.180, p<0.05)$. The t-value of 5.180 shows that the coefficient of the model parameter is statistically significant $(p=0.001)$. The result shows $R$ square value of 0.105 shows that $10.5 \%$ of the variation in entrepreneurial innovationof selected SMEs in Aba metropolis can be explained by entrepreneurial orientation and at 95\% confidence level. The regression equation showed that a unit increase in the entrepreneurial orientation, that is, increasing SMEs entrepreneurial behaviour by a unit would result in increased entrepreneurial innovation by 0.271 . From the study at $95 \%$ confidence level, entrepreneurial orientation produced statistically significant values that were greater that 0.05 of $\mathrm{p}$-value which is the standard. The p-value for entrepreneurial orientation was found to be 0.001 from the coefficient table and this is less than 0.05 hence the model can be accepted to produce significant result. The result showed a significant influence of entrepreneurial orientation on entrepreneurial innovation of small and medium enterprises in Aba metropolis.

\section{CONCLUSION AND RECOMMENDATIONS}

The effect of strategic entrepreneurship on the performance of small and medium scale enterprises in the Aba metropolis, Abia State was assessed, and the major issues that emerged from the findings showed that: Entrepreneurial education have significant influence on entrepreneurial efficiency of selected SMEs in Aba metropolis $\left(\mathrm{R}^{2}=0.076, \mathrm{p}<0.05\right)$. Entrepreneurial leadership has significant effect on employee turnover intention of selected SMEs in Aba metropolis $\left(\mathrm{R}^{2}=0.053, \mathrm{p}<0.05\right)$. Entrepreneurial knowledge have significant effect on entrepreneurial skills of selected SMEs in Aba metropolis $\left(R^{2}=0.132, p<0.05\right)$. Entrepreneurial orientation does not influence entrepreneurial innovation of selected SMEs in Aba metropolis $\left.\mathrm{R}^{2}=0.105, \mathrm{p}<0.05\right)$. It is concluded that strategic entrepreneurship plays an important role in enhancing the performance of small and medium scale enterprises in Aba metropolis (entrepreneurial efficiency, employee turnover intention, entrepreneurial skills and entrepreneurial innovation). 
The finding that entrepreneurial education has a significant effect on entrepreneurial efficiency of SMEs will benefit the owner/manager of SMEs in being proactive towards a continuous effective entrepreneurial education of their employees on a regular basis to ensure efficiency of operations. The findings that entrepreneurial orientation has a significant effect on entrepreneurial innovation of SMEs will also benefit the owner/ manager of SMEs in orienting their employees on new ways of production, packaging and delivery in order to form the best innovation strategies and policies that will boost the enterprise's performance and in meeting their customers' needs. Also, the finding that entrepreneurial leadership has a significant influence on employee turnover intention of SMEs will benefit the owner/ manager by helping them adopt the best type of leadership in running their business in which transformational leadership is suitable as it is likely to reduce the rate of employee turnover intention of SMEs. The finding that entrepreneurial knowledge has a significant effect on entrepreneurial skills of SMEs will also benefit the owner/ manager in organizing monthly programmes and seminars that will enhance the entrepreneurial skills of the SMEs towards increased productivity. The finding that entrepreneurial orientation has a significant effect on entrepreneurial innovation of SMEs will benefit the government towards formulating favourable policies that will encourage entrepreneurial innovation of new products and new technology of SMEs.

Based on the findings and conclusion presented, it is recommended that in order for SMEs in Aba metropolis to operate competitively, profitably and significantly contribute to the economic recovery and growth of Nigeria, the owner/ management need to continuously acquire entrepreneurial education for themselves and their employees. Also, leaders or managers of SMEs in Aba metropolis need to engage more in transformational leadership style as this is likely to reduce the rate of employee turnover intention. In addition, the owner/management needs to increase the level of entrepreneurial knowledge they have in order to acquire more skills to operate efficiently in order to gain competitive advantage. Furthermore, owner/ management of SMEs in Aba metropolis should be able to orient their employees both the existing staff and the newly recruits on new ways of production and ways of product innovation through periodic market research.

Future research should be carried out to ascertain the relationship among the four different strategic entrepreneurship variables. This will provide in-depth clarification with regard to how each variable of strategic entrepreneurship relates to one another as well as how that relationship enhances performance. Also, collection of data state-wide will ensure good spread and robustness of data analysis. Other factors not studied in this research contributed $89.5 \%$ of variance in entrepreneurial innovation. Therefore, further research should be conducted to establish the influence of other factors not analyzed in this study on entrepreneurial innovation of small and medium enterprises in Aba metropolis.

\section{References}

Abanis, T., Arthur, S., Byamukama, E., Burani, A., Ibrahim, Y., \& Novembrieta, S. (2013). Business efficiency in small and medium enterprises selected districts in western Uganda. Research Journal of Finance and Accounting, 2(4), 19-28.

Abimiku, J., \& Mohammed, A. (2015). Innovation among small and medium enterprises in Nigeria. Journal of Resourcefulness and Distinction, 1(11), 1-13.

Adbu, M. \& Jibir, A. (2017). Determinants of firms innovation in Nigeria. Journal of Social Sciences, xxx(2017), 1-9 http://dx.doi.org/10.1016/j.kjss.2017.07.006

Adisa, M. K., Adeoye, A. O. \& Okunbanjo, O. I. (2016). The impact of entrepreneurship orientation on entrepreneurs compensation in Nigeria. International Journal of Economics, Business and Management Studies, 3(3), $102-116$.

Afolabi, B. \& Macheke, R. (2012). An analysis of entrepreneurial and business skills and training needs in SMEs in the plastic manufacturing industry in the eastern cape province, South Africa. International Review of Social Sciences and Humanities, 2(3), 236-247. 
Agarwal, S. P. \& Ashwani, G. (2008). Policies and mechanisms for technology transfer to SMEs in a globalizing economy - Indian perspectives. India: Economic, Political and Social Issues. India: Nova Science Publishers

Agarwal, R., Audretsch, D., \& Sarkar, M. (2010). The process of creative construction: Knowledge spillovers, entrepreneurship and economic growth. Strategic Entrepreneurship Journal, 1(2), 263-286.

Agbim, K. C., Oriarewo, G. O., \& Owutuamor, Z. B. (2013). An exploratory study of the entrepreneurial leadership capabilities of entrepreneurs in Anambra State, Nigeria. Journal of Business Management \& Social Sciences Research 2(9), 68-75

Akhamiokhor, S. \& Adanikin, A. (2017). Entrepreneurial strategies and small and medium scale enterprises (SMEs) development in Ogun State, Nigeria. International and Public Affairs Journal, 1(1), 34-38.

Armstrong, M. (2006). A hand book of human resource management, (10 th ed). London: Kogan Page

Audretsch, B., Lehmann, E., Belitski, M., \& Caiazza, R. (2018). Knowledge management in entrepreneurial organizations. Special Issue of the International Entrepreneurship and Management Journal, 1554-7191.

Avolio, B. J. \& Yammarino, F. J. (2013). Transformational and charismatic leadership: The road ahead. Emerald Group Publishing

Avlonitis, G., \& Salavou, H. (2007). Entrepreneurial orientation of SMEs, product innovativeness, and performance. Journal of Business Research, 60(5), 566-575.

Barchue, J., \& Aikaeli, J. (2013). Efficiency of small and medium sized enterprises in Liberia: the case of Monrovia. University of Dar er Salam, 8(2). 90-107

Barney, J (2007). Gaining and sustaining competitive advantage. (3rded.). Upper Saddle River, NJ: Pearson Education.

Barney, J. B., Ketchen, Jr. D. J. \& Wright, M. (2011). The future of resource-based theory: Revitalization or decline. Journal of Management, 37, 1299-1315.

Bassey, E. B. \& Tapang, A. T. (2012). Capitalized human resources cost and its influence on corporate productivity: a study of selected companies in Nigeria. International Journal of Financial Research, 3(2), 48-59

Bengesi, K. M. K. \& Roux I. L. (2014). Strategic entrepreneurial response of small and medium enterprises in developing economies. International Journal of Business and Management, 9(2), 153 - 165

Bleeker, I. (2011). The influence of entrepreneurial orientation on the innovation process: An empirical research on manufacturing SMEs. Masters Thesis, University of Twente

Bosire, K., \& Nzaramba, K. (2013). Entrepreneurship skills development and growth of small and medium enterprises in Rwanda. Int. J. Infor. Technol. Bus. Manage. 1(17), 12-28.

Bryman, A. (2012). Social research methods (4th ed.). New York: Oxford University Press.

Burger, L. O'Neil, C. \& Mahadea, P. (2005). The impact of previous knowledge and experience on the entrepreneurial attitude of grade learners, South African Journal Education, 25(2), 29-94

Chen, M. H. (2007). Entrepreneurial leadership and new ventures: creativity in entrepreneurship. Creativity and Innovation Management, 16(3), 239-249

Cheng, B., Ioannou, I. \& Sefafeim, G. (2013). Corporate social responsibility and access to finance. Strategic Management Journal 35(1), 1-23

Chen, Y. Tang, G., Jin, J., Xie, Q. \& Li, J. (2014). CEO;s transformational leadership and product innovation performance: the roles of corporate entrepreneurship and technology orientation. Journal of Product Innovation Management, 31(S1), 2-17

Cheng, C., Bartram, T., Karimi, L., \& Leggat, S. (2016). Transformational leadership and social identity as predictors of team climate, perceived quality of care, burnout and turnover intention among nurses. Personnel Review, 45(6), 1200-1216.

Claudio, T. B., Santos, M. D., Cabral, C. A. \& Pessoa, N. M. (2017). Fostering and limiting factors of innovation in micro and small enterprises. Innovative and Management Review, 14(2), 130-139

Cogliser, C. C. \& Brigham, K. H. (2004). The intersection of leadership and entrepreneurship: mutual lessons to be learned. Leadership Quarterly, 15, 771-799

Cooper, D. R., \& Schindler, P. S. (2011). Business research methods. (11th ed.). New York: McGraw-Hill. 
Covin, J. \& Wales, W. (2012). The measurement of entrepreneurial orientation. Entrepreneurship Theory and Practice, 36(4), 677-702.

Covin, J., \& Slevin, D. (2002). The entrepreneurial imperatives of strategic leadership. Oxford, UK: Blackwell Publishers.

Daniya, A. \& Oni, O. (2012). Development of small and medium scale enterprises: the role of government and other financial institutions. Arabian journal of business and management review, 7(1), 16-29.

Dapend, Y., Jin, C. \& Sonting, P. (2016). A process study of strategic entrepreneurship:

viewing from ambidexterity and dynamic capability. $3^{\text {rd }}$ International Conference on Education, Management and Computing Technology. Singapore, July 9-11

Dauda, O. (2007). Entrepreneurship Education. Learning Organization, 5(3), 144.155.

Didenko, A. \& Pliego, G. S. (2014). Knowledge transfer in project-based SMEs: Transfer of project lessons-learned between project managers. Masters Thesis, Umea School of Business and Economics

Dzever, D., Ayoola, B., Alakali, J., Atar, I., Sanni, L., Ngadi, M., \& Kok, R. (2016). Technical efficiency among small and medium scale entrepreneurs in high quality cassava flour in four geo-political zones of Nigeria. European Journal of Physical and Agricultural Sciences, 3(4), 52-64

Ebitu, E., Basil, G., \& Ufot, A. (2016). An appraisal of Nigeria's micro, small and medium enterprises (MSMES): growth, challenges and prospects. International Journal of Small Business and Entrepreneurship Research, 4(4), 115

El Badawy, T., \& Bassiouny, M. (2014). Employee engagement as a mediator between transformational leadership \& intention to quit. International Journal of Contemporary Management, 13(2), 152-160.

Eleodinmuo, 0. (2015). Analysis of entrepreneurship policy for small and medium scale enterprise in Aba, Abia State, Nigeria. Journal of Economic Development, Management, IT, finance and marketing, 7(1), 47-60.

Eleodinmuo, O., \& Onwumere, J. (2015). Enhancing innovativeness among small and medium scale enterprises (SMEs) to boost performance in Abia State, Nigeria. International Journal of Community and Cooperative Studies, 1(3), 1-14.

Eniola, A. A. (2014). The role of SME firm performance in Nigeria. Arabian Journal of Business and Management Review (Oman Chapter), 3(12), 33-47

Etriya, I., Scholten, V., Wubben, E., Kemp, R. \& Omta, S. W. F. (2013). The impact of entrepreneurial orientation on innovation adoption and innovation generation and ultimately performance of vergetable farmers in West Java, Indonesia. The $3^{\text {rd }}$ AGRIMBA=AVA Congress, Budva, Montennegro, June 25-30

Fairoz, F. M., Hirobumi, T. \& Tanaka, Y. (2010). Entrepreneurial orientation and business performance of small scale enterprises of Hambantota District Sri Lanka. Asian Social Science, 6(3), 34-46

Farja, Y., Gimmon, E., \& Greengerg, Z. (2016). The effect of entrepreneurial orientation on SMEs growth and export in Israeli peripheral regions. New England Journal of Entrepreneurship, 19(2), 25-40

Foss, J. N., \& Lyngsie, J. (2011). The emerging strategic entrepreneurship field: origins, key tenets, and research gaps. Working paper No 7/2011.

Galbreath, J. \& Galvin, P. (2006). Accounting for performance variation: how important are intangible resources? International Journal of Organizational Analysis, 14(2), 150-170

Gast, J., Werner, A., \& Kraus, S. (2016). Antecedents of the small firm effect; the role of knowledge spillover and blocked mobility for employee entrepreneurial intentions. International Entrepreneurship Management Journal, Springer science + Business media, New York.

Griffith, J. (2003). Relation of principal transformational leadership to school staff job satisfaction, staff turnover, and school performance. Journal of Educational Administration, 42(3), 333-356.

Gul, S., Ahmad, B., Rehman, S., Shabir, N., \& Razzaq, N. (2012). Leadership Styles, turnover intentions and the mediating role of organizational commitment. Information and Knowledge Management, 2(7), 44-51.

Gupta, V., MacMillan, I. C. \& Surie, G. (2004). Entrepreneurial leadership: developing and measuring a crosscultural construct. Journal of Business Venturing, 19(2), 241-260

Gyensare, M. A, Anku-Tsede, O., Sanda, M. A., \& Okpoti, C. A. (2016). Transformational leadership and employee turnover intention. World Journal of Entrepreneurship, Management and Sustainable Development, 12(3), 243-266 
Gyensara, M. A., Kumedzo, L. E., Sanda, M. A. \& Boso, N. (2017). Linking transformational leadership to turnover intention in the public sector: the influences of engagement, affective commitment and psychological climate. African Journal of Economic and Management Studies, 8(3), 314- 337.

Hisrich, R. D. \& Peters, M. P. (2002). Entrepreneurship, (5 ${ }^{\text {th }}$ Ed). Sydney: McGraw-Hill

Hitt, M. A., Ireland, D., Camp, M. \& Sexton, D. L. (2001). Strategic entrepreneurship: entrepreneurial strategies for wealth creation. Strategic Management Journal, 22, 479-491

Hongvichit, S. (2015). The research progress and prospect of employment turnover intention. International Business Research, 8(6), 218- 233

Ibrahim, M., \& Shariff, M. (2016). Mediating role of access to finance on the relationship between strategic orientation attributes and SMEs performance in Nigeria. Int. J. Bus. Soc. 17(3), 473-496.

Ireland, R., Hitt, M., \& Sirmon, D. (2003). A model of strategic entrepreneurship: The construct and its dimensions. Journal of Management, 29(6), 963-989.

Ismail, A., Rose, R., Uli, J., \& Abdullah, H. (2012). The Relationship between organisational resources, capabilities, systems and competitive advantage. Asian Acad. Manage. J. 17(1), 151-173.

Izedonmi, P. F. \& Okafor, C. (2010). The effect of entreprnuership education on students entrepreneurial intention. Global Journal of Management and Business Research 10(6), 49-60

Jafarnejad, A., Abbaszadeh, A.M., Ebrahimi, M. \& Abtahi, S. M. (2013). Analysis of barriers to entrepreneurship in Small and Medium-sized Enterprises (SMEs). International Journal of Academic Research in Economics and Management Sciences. 4(2), 207-216.

Kim, S., Kim, J-N \& Rhee, Y. (2017). Determinants of employee turnover intention: Understanding the roles of organization justice, supervisory justice, authoritarian organizational culture and organization-employee relationship quality. Corporate Communications: An International Journal, 22(3), 308-328

Kraaijenbrink, J., Spender, J. C. \& Groen, A. J. (2010). The Resource=Based View: a review and assessment of its critiques. Journal of Management, 36(1), 349-372

Kaiser, H. F. (1974). An index of factorial simplicity. Psychometrika, 39(1), 31-36

Kleysen, R. F. \& Street, C. T. (2001). Towards a multi-dimensional measure of individual innovative behavior. Journal of Intellectual Capital, 2(3), 284-296

Kumar, R., Ramendran, C. \& Yacob, P. (2012). A study on turnover intention in fast food industry: employees; fit to the organizational culture and the important of their commitment. International Journal of Academic Research in Business and Social Sciences, 2(5), 9- 20

Kuratko, D. F. (2017). Corporate entrepreneurship 2.0: research development and future directions. Foundations and Trends in Entrepreneurship, 13(6), 441-490

Kuratko, D. F. \& Audretsch, B. (2017). Strategic Entrepreneurship: Exploring different perspectives of an emerging concept. Entrepreneurship Theory and Practice Journal, 33(1), 1-7.

Kurnat-Thoma, E., Ganger, M. Peterson, K. \& Channell, L. (2017). Reducing annual hospital and registered nurse staff turnover - A 10-elelment onboarding program intervention. Open Nursing, 3, 1-13

Kropp, F. Lindsay, N. J. \& Sholam, A. (2007). Entrepreneurial, market, and learning orientations and international entrepreneurial business venture performance in South African firms. International Marketing Review, 23(5), 504-523

Liu, L., Timothy, V. \& Gao, Y. (2010). A review of approaches of resource-based empirical research in banking. The International Journal of Applied Economics and Finance, 4(4), 230-241

Luke, B. (2009). Strategic entrepreneurship in New Zealand's state -owned enterprises. Underlying elements and financial implications. PhD Thesis, Aukland University of Technology

Lumpkin, G., \& Dess, G. (2001). Linking two dimensions of entrepreneurial orientation to firm performance: The moderating role of environment and industry life cycle. Journal of Business Venturing, 16(5), 429-451

Madanchian, M., \& Taherdoost, H. (2017). Role of leadership in small and medium enterprises (SMEs). International Journal of Economics and Management Systems, 2, 240-243. 
Madhoushi, M., Sadati, A., Delavari, H., Mehdivand, M., \& Mihandost, R. (2011). Entrepreneurial orientation and innovation performance: the mediating role of knowledge management. Asian journal of business management, 3(4), 310-316.

Majama, N. S. \& Magang, I. T. (2017). Strategic planning in small and medium enterprises (SMEs): A case study of Botswana SMEs. Journal of Management and Strategy, 1(8), 74-103.

Majeed, N., Jamsheda, S., Mustamila, N.M. (2018). Striving to restrain employee turnover intention through ethical leadership and pro-social rule breaking. International Online Journal of Educational Leadership, 1(2), 39-53.

Maria, M. (2010). Entrepreneurship and entrepreneurship education origins. Journal of Economic Behavior \& Organisation, 76, 90-112

Mark, J. \& Nwaiwu, J. N. (2015). Impact of political environment on business performance of multinational companies in Nigeria. African Research Review, An International Multidisciplinary Journal, Ethiopia, 3 (9), 1-10.

Martin, M. \& Namusonge, M. (2014). Influence of innovation on small and medium enterprise (SME) growth. International Journal for Innovation Education and Research, 2(5), 31-41

Massad, J. V. \& Tucker, J. M. (2009). Using student managed business to integrate the business curriculum. Journal of Instructional Pedagogies, 17-29

Maylew, R. (2013). Employee turnover, definitions and calculations. New York: Demand Media

Mazler, K., Grabner-Krauter, S. \& Bidmon, S. (2008). Risk aversion and brand loyalty: the mediating role of brand trust and brand effect. Journal of Product and Brand Management, 17(3), 154-162

Meutia, \& Ismail, T. (2012). The development of entrepreneurial social competence and business network to improve competitive advantage and business performance of small medium sized enterprises: a case of Batik Industry in Indonesia. Procedia-Social and Behaioral Sciences, 65, 46-51

Mitchelmore, S., \& Rowley, J. (2010). Entrepreneurial competencies: A literature review and development agenda. Int. J. Entrepreneurial Behav. Res. 16(2), 92-111.

Mohammed, D., \& Obeleagu-Nzelibe, C. (2014). Entrepreneurial skills and profitability of small and medium enterprises (SMEs): Resource acquisition strategies for new ventures in Nigeria. Proceedings of 25th International Business Research Conference 13 - 14 January, 2014, Taj Hotel, Cape Town, South Africa.

Mohutsiwa, M. (2012). Strategic entrepreneurship and performance of small and medium enterprises in South Africa, A research report submitted to the Faculty of Commerce, Law and Management, University of the Witwatersrand.

Njenga, G., \& Theuri, F. (2016). The role of entrepreneurship training and education in enhancing growth of small and medium enterprises in Kenya: A case study of Mombasa country. Journal of Humanities and Social Science, 21, 97-106.

Njoroge, C., \& Gathungu, M. (2013). The effect of entrepreneurial education and training on development of small and medium size enterprises in Githunguri district-Kenya. International Journal of Education and Research, 8(1), 122.

Nowak, P. Holmes, G. \& Murrow, J. (2010). A model for reducing health care employee turnover. Journal of Hospital Marketing \& Public Relations. 20(1): 14-25

Nunnally, J. C. (1978). Psychometric theory (2nd ed.). NewYork: McGraw-Hill

Nyaga, R. (2015). Assessment of employee turnover on organizational efficiency: a case study of International Livestock Research Institute (ILRI). MSc Thesis, United States International University-Africa

Nystrom, K. (2012). Entrepreneurial Employees: Are they different from independent entrepreneurs? Division of Economics, department of industrial economics and management. The royal institute of technology, Lindstedsv, Stockholm, Sweden, 1-12.

Obiwuru, T., Okwu, A., Akpa, V., \& Nwankwere, I. (2011). Effects of leadership style on organizational performance: A survey of selected small scale enterprises in Ikosi-Ketu Council Development Area of Lagos state, Nigeria. Australian Journal of Business and Management Research, 7(1), 100-111.

Ogunyomi, P., \& Bruning, N. (2015). Human resource management and organizational performance of small and medium enterprises (SMEs) in Nigeria. Int. J. Human Res. Manage. 27(6), 612-634.

Okudan, G. E. \& Rzasa, S. E. (2006). A project-based approach to entrepreneurial leadership education.

Technovation, 26, 195-210 
Omare, J. O. \& Kyongo, J.K. (2017). Effect of entrepreneurial skills on competitive advantage among small and medium size enterprises. International Journal of Economics, Commerce and Management. 7(5), 173-180.

Padachi, K. (2012). Factors Affecting the Adoption of Formal Accounting Systems by SMEs. Business and Economics Journal, 67, 1-20

Pallant, J. (2010). SPSS survival manual: a step by step guide to data analysis using the SPSS program (4th $e d$ ). New York: McGraw Hill

Park, S, and Luo, Y. (2001). Guanxi and organizational dynamics: organizational networking in Chinese organisations. Strategic Management Journal, 22(5), 455-477

Perez-Luno, A., Wiklund, J. \& Cabrere, R. V. (2011). The dual nature of innovative activity: how entrepreneurial orientation influences innovation generation and adoption. Journal of Business Venturing, 26(5), 555-571

Qosja, E. (2014). Innovation, SMEs, and the entrepreneurship education related to them, journal of educational and social research. MCSER Publishing Rome-Italy, 6(4), 69-74.

Rezeai, J. \& Ortt, R. (2018). Entrepreneurial orientation and firm performance: the mediating role of functional performances. Management Research Review, 41(7), 878-900

Saasongu, N. (2015). Effects of leadership style on organizational performance in small and medium scale enterprises (SMEs) in Nigeria. International Journal of Research in Management and Business Studies, 2 (1), 23-30.

Salisu, Y. \& Abu Baker, L. J. (2018). Technological collaboration, technological capability and SMEs product innovation performance. International Journal of Management Research \& Review, 8(2), 1-13

Schindehutte, M., \& Morris, M. (2009). Advancing strategic international research: the role of complexity science in entrepreneurship theory and practice shifting the paradigm, Theory and Practice, 33(1), 241-276

Schueffel, P. (2014). The effects of EO on innovation performance, open innovation proclivity and openness. Academy of Management Proceedings, 2014(1), 1-9

Sidek, S., Mohamad, M. R. \& Nasir, W. M. (2016). Entrepreneurial orientation access to finance and business performance: a preliminary analysis. International Journal of Academic Research in Business and Social Sciences, 6(11), 692-707

Siew, K. (2017). Analysis of the relationship between leadership styles and turnover intention within small medium enterprise in Malaysia. Journal of Arts and Social Sciences, 1, 1-11

Simmons, J D. (2010). The effects of firms size on the entrepreneurial orientation dimensions of innovativeness, proactiveness and risk taking. Masters Thesis, Ohio University

Surie, G. \& Ashley, A. (2008). Integrating pragmatism and ethics in entrepreneurial leadership for sustainable value creation. Journal of Business Ethics, 81(1), 235-246

Tim, F. M. (2011). The influence of entrepreneurs on employees' affective commitment in micro and small organisations. MSc Thesis, Tilburg University

Tshikovhi, N. \& Shambare, R. (2015). Entrepreneurial knowledge, personal attitudes and entrepreneurship intentions among South African Enactus students. Problems and Perspectives in Management, 13(1-1), 152-158

Tywoniak, S. (2007). Making sense of the resource-based view? Philadelphia: Proceedings of Academic Management

Waldman, D. A., Carter, M. Z. \& Hom, P. W. (2015). A multilevel investigation of leadership and turnover behvaviour. Journal of Management, 41(6), 1724-1744

Wells, J. E. \& Peachey, J. W. (2010). Turnover intentions: do leadership behaviors and satisfaction with the leader matter? Team Perform. Manage., 17, 23-40

Wernerfelt, B. (1984). The resource-based view of the firm. Strat. Manage. J. 5(2), 171-180.

Yusuf, E. (2017). Influence of entrepreneurship education, technology and globalization on performance of SMEs in Nigeria. African journal of business management, 15(11), 367- 374.

Zafar, A., \& Mustafa, S. (2017). SMEs and Its Role in Economic and Socio-Economic Development of Pakistan. International Journal of Academic Research in Accounting, Finance and Management Sciences, 4(6). 1-16.

Zhai, Y., Sun, W., Tsai, S., Wang, Z., Zhao, Y., \& Chen, Q. (2018). An empirical study on entrepreneurial orientation, absorptive capacity, and SME's innovation performance: A sustainable perspective. Sustainability Journal, 10, 1-14. 
Zhara, S, A., Ireland, R. D. \& Hitt, M. A. (2000). International expansion by new venture firms: international diversity, mode of market entry, technological learning and performance. Academy of Management Journal, 43(5), 925-959 